\title{
Chromium Bioaccumulation and Its Impacts on Plants: An Overview
}

\author{
Anket Sharma ${ }^{1, *+\dagger} \mathbb{D}$, Dhriti Kapoor ${ }^{2,+}$, Junfeng Wang ${ }^{1,+}$, Babar Shahzad ${ }^{3}$, Vinod Kumar 4 (D), \\ Aditi Shreeya Bali ${ }^{5}$, Shivam Jasrotia ${ }^{6}$, Bingsong Zheng ${ }^{1} \mathbb{D}$, Huwei Yuan ${ }^{1, *}$ and Daoliang Yan ${ }^{1, *}$ \\ 1 State Key Laboratory of Subtropical Silviculture, Zhejiang A\&F University, Hangzhou 311300, China; \\ 2017702431011@stu.zafu.edu.cn (J.W.); bszheng@zafu.edu.cn (B.Z.) \\ 2 School of Bioengineering \& Biosciences, Lovely Professional University, Punjab 144411, India; \\ dhriti405@gmail.com \\ 3 School of Land and Food, University of Tasmania, Hobart, Tasmania 7005, Australia; \\ Babar.shahzad@utas.edu.au \\ 4 State Higher Education Department, Jammu and Kashmir 180001, India; vinodverma507@gmail.com \\ 5 Mehr Chand Mahajan D.A.V. College for Women, Chandigarh 160036, India; shreeyaaditi02@gmail.com \\ 6 Department of Zoology, Guru Nanak Dev University, Amritsar 143005, India; shivbaba1990@gmail.com \\ * Correspondence: anketsharma@gmail.com (A.S.); hwyuan@zafu.edu.cn (H.Y.); liangsie@zafu.edu.cn (D.Y.); \\ Tel.: +86-571-63732738 (H.Y.); +86-571-63732761 (D.Y.) \\ + Authors contributed equal.
}

Received: 29 October 2019; Accepted: 9 January 2020; Published: 13 January 2020

\begin{abstract}
Chromium (Cr) is an element naturally occurring in rocky soils and volcanic dust. It has been classified as a carcinogen agent according to the International Agency for Research on Cancer. Therefore, this metal needs an accurate understanding and thorough investigation in soil-plant systems. Due to its high solubility, $\mathrm{Cr}$ (VI) is regarded as a hazardous ion, which contaminates groundwater and can be transferred through the food chain. $\mathrm{Cr}$ also negatively impacts the growth of plants by impairing their essential metabolic processes. The toxic effects of $\mathrm{Cr}$ are correlated with the generation of reactive oxygen species (ROS), which cause oxidative stress in plants. The current review summarizes the understanding of $\mathrm{Cr}$ toxicity in plants via discussing the possible mechanisms involved in its uptake, translocation and sub-cellular distribution, along with its interference with the other plant metabolic processes such as chlorophyll biosynthesis, photosynthesis and plant defensive system.
\end{abstract}

Keywords: heavy metal; reactive oxygen species; oxidative burst; antioxidants

\section{Introduction}

Chromium $(\mathrm{Cr})$ is a silver-colored hard metal naturally occurring in rocky soils, and volcanic dust. Chromium is the 24th element having a molecular weight of 51.1 a.m.u. and a density of $7.19 \mathrm{~g} / \mathrm{cm}^{3}$ [1]. The Agency for Toxic Substances and Disease Registry [2] has ranked $\mathrm{Cr}$ the 17th among the most hazardous substances. It has been classified as the number one carcinogen according to the International Agency for Research on Cancer [3]. Therefore, this metal needs an accurate understanding of its uptake, transport and bioaccumulation within plants and a thorough investigation in soil-plant systems.

Chromium can easily convert from one oxidation state to another due to its high redox potential and intricate electronic and valence shell chemistry [4,5]. It exists in a wide range of oxidation states, but the most common and stable states are Cr (VI) "hexavalent" and Cr (III) "trivalent" [6]. Both forms of $\mathrm{Cr}$ vary significantly with respect to their bioavailability in soil, translocation and toxicity within plants [4]. The $\mathrm{Cr}$ (III) occurs in the form of chromite $\left(\mathrm{FeOCr}_{2} \mathrm{O}_{3}\right)$, whereas $\mathrm{Cr}$ (VI) occurs in 
association with oxygen to form chromate $\left(\mathrm{CrO}_{4}{ }^{2-}\right)$ or dichromate $\left(\mathrm{Cr}_{2} \mathrm{O}_{7}{ }^{2-}\right)$, that are highly toxic to living organisms [7]. Based on its activity, former is the most stable form of $\mathrm{Cr}$, whereas the highest noxious one for plants is the $\mathrm{Cr}(\mathrm{VI})$. Under physiological conditions, $\mathrm{Cr}(\mathrm{VI})$ enters the cells and may get reduced to $\mathrm{Cr}(\mathrm{V}), \mathrm{Cr}(\mathrm{IV})$, thiylradicals, hydroxyl radicals and finally $\mathrm{Cr}$ (III). All these oxidation states disrupt the cellular integrity of cells by attacking proteins, DNA and membrane lipids [8,9].

Hexavalent $\mathrm{Cr}$ (VI) is used in several industrial applications such as electroplating, dyeing of textiles, leather processing, steel production and tanning industry, resulting in discharge of chromium-containing effluents. This ultimately causes significant elevation in $\mathrm{Cr}$ contents in the environment [10]. Due to its high solubility in water and soil, $\mathrm{Cr}$ (VI) is regarded as a hazardous ion that contaminates groundwater and can be transferred through the food chain [10-12]. It also occurs in air, water and soil at different concentrations. Its contents in freshwater and seawater vary from 0.1 to $117 \mu \mathrm{g} \mathrm{L}^{-1}$ and 0.5 to $50 \mu \mathrm{g} \mathrm{L}^{-1}$ respectively. The weathering of $\mathrm{Cr}$ containing rocks and leaching of soils discharge significant $\mathrm{Cr}$ contents into the aquatic environment [7]. Cr contents in soil ranges between 10 and $50 \mathrm{mg} \mathrm{kg}^{-1}$ under natural conditions, however, its concentration in agricultural soils can reach up to $350 \mathrm{mg} \mathrm{kg}^{-1}$ of the soil [7]. The United States Environmental Protection Agency (USEPA) [13] has listed $\mathrm{Cr}$ among the 14 most dangerous substances that can cause serious health issues in living organisms. Cr can have both beneficial and harmful effects on human health depending on its uptake, exposure time and oxidation state. The trivalent form of $\mathrm{Cr}$ (III) is an important nutrient for humans and according to the World Health Organization [14], its daily ideal intake is between 50 and $200 \mu \mathrm{g} \mathrm{day}^{-1}$ for the metabolism of carbohydrates, proteins and fatty acids. However, its excess in the body poses serious health concerns. Moreover, hexavalent $\mathrm{Cr}(\mathrm{VI})$ is $10-100$ folds more harmful than $\mathrm{Cr}$ (III), which can cause allergies and skin problems.

To date, $\mathrm{Cr}$ does not have any known biological role in plant physiology [15]. It is generally perceived that excessive $\mathrm{Cr}$ levels in plant tissues may provoke several morpho-physiological and biochemical processes in plants $[16,17]$. Any metal toxicity is attributed to a complex series of metal interactions with the genetic processes, signal transduction and pathways and cellular macromolecules [18-20]. Hence, $\mathrm{Cr}$ toxicity is reported to affect plant growth and impedes their essential metabolic processes [21]. Typically, $\mathrm{Cr}$ toxicity reduces plant growth by inducing ultrastructural modifications of the cell membrane and chloroplast, persuading chlorosis in the leaves, damaging root cells, reducing pigment content, disturbing water relations and mineral nutrition, affecting transpiration and nitrogen assimilation and by altering different enzymatic activities [15,22-25]. All these toxic effects of $\mathrm{Cr}$ might be due to the over production of reactive oxygen species (ROS), which ultimately disrupt the redox balance in plants [25]. Taking all into consideration, we review the literature that addresses $\mathrm{Cr}$ uptake, translocation and sub-cellular distribution in plants. We also discuss different effects of $\mathrm{Cr}$ on plant pigments, photosynthetic parameters, enzymatic and non-enzymatic antioxidative system and various endogenous levels of plant hormones (Table 1).

Table 1. Effects of chromium metal on different physiological processes in plants.

\begin{tabular}{ccc}
\hline Plant Species & Physiological Response & Reference \\
\hline Camellia sinensis & Increased SOD and CAT activities & Tang et al. [26] \\
\hline Capsicum annuum & Increased carotenoid content & Oliveira [27] \\
\hline Chamomilla recutita & Increased MDA level & Kováčik et al. [28] \\
\hline Echinochloa colona & Increased CAT and POD activities & Samantaray et al. [29] \\
\hline Kandelia candel & $\begin{array}{c}\text { Increased MDA content, and } \\
\text { activities of CAT and SOD }\end{array}$ & Rahman et al. [30] \\
\hline Ocimum tenuiflorum & Increased proline level & Rai et al. [31] \\
\hline Oryza sativa & Increased POD activity & Ma et al. [32]
\end{tabular}


Table 1. Cont.

\begin{tabular}{ccc}
\hline Plant Species & Physiological Response & Reference \\
\hline Oryza sativa & Increased ethylene synthesis & Trinh et al. [33] \\
\hline Oryza sativa & Increased CAT and SOD activities & Zhang et al. [34] \\
\hline Oryza sativa & Increased POD activity & Xu et al. [35] \\
\hline Phaseolus vulgaris & Decreased carotenoids & Aldoobie and Beltagi [36] \\
\hline Pisum sativum & Decreased APX activity & Duhan [37] \\
\hline Pterogyne nitens & Increased spermidine level & Paiva et al. [38] \\
\hline Raphanus sativus & Increased glycine-betaine content & Choudhary et al. [39] \\
\hline Triticum aestivum & Increased MDA contents & Ali et al. [22] \\
\hline Triticum aestivum & Increased lipid peroxidation & Zhang et al. [34] \\
\hline Vigna radiata & Decreased glutathione level & Shanker et al. [40] \\
\hline Zea mays & Increased SOD and GPX activities & Maiti et al. [41] \\
\hline Zea mays & Increased lipid peroxidation and & Maiti et al. [41] \\
\hline
\end{tabular}

Abbreviations: Malondialdehyde-MDA; Superoxide dismutase-SOD; Catalase-CAT; Ascorbate peroxidaseAPX; Peroxidase-POD; Guaiacol peroxidase-GPX; Hydrogen peroxide- $-\mathrm{H}_{2} \mathrm{O}_{2}$.

\section{Chromium Uptake, Translocation and Sub-Cellular Distribution}

Plant roots secrete various organic acids such as citrate and malate that modify the solubility of metals present in insoluble form in the soil by acting as ligands [42-45]. Srivastava et al. [46] had shown an increased accumulation of $\mathrm{Cr}$ in tomato plants due to the presence of citrate, aspartate and oxalate, which converted inorganic $\mathrm{Cr}$ into organic complexes, which are readily available for the plant to uptake. Chromium appears to have no essential role in plant metabolism, hence, there is no specific mechanism for its uptake in plants [27]. Skeffington et al. [47] had proposed a mechanism for uptake of both $\mathrm{Cr}$ (III) and $\mathrm{Cr}$ (VI) in barley (Hordeum vulgare) plants. Nonetheless, specific carriers responsible for the absorption of essential ions also aid in the uptake of $\mathrm{Cr}$ [4]. The uptake of $\mathrm{Cr}$ (III) in plants undergoes through passive mechanism [48], however, $\mathrm{Cr}(\mathrm{VI})$ is uptaken through the plasma membrane, which is an active process involving carriers of essential anions such as sulfate $[49,50]$. Further, due to the structural similarity of $\mathrm{Cr}(\mathrm{VI})$ with phosphate and sulfate, its uptake by root cells involves phosphate or sulfate transporters [51,52].

The distribution and translocation of $\mathrm{Cr}$ within plants depend upon the plant species, the oxidation state of the $\mathrm{Cr}$ ions, and also its concentration in the growth medium [4]. Compared to other heavy metals, the mobility of $\mathrm{Cr}$ in the plant roots is low. Therefore, the concentration of $\mathrm{Cr}$ in the roots is sometimes 100 times higher than in the shoots $[48,53]$. For instance, $\mathrm{Cr}$ concentration was observed to be highest in the cytoplasm and intercellular spaces of rhizome and root cell wall of Iris pseudacorus [54]. The higher accumulation of $\mathrm{Cr}$ in roots might be attributed to the sequestration of $\mathrm{Cr}$ in the vacuoles of root cells as a protective mechanism [55]. Thus, this mechanism provides some natural tolerance to plants towards $\mathrm{Cr}$ toxicity [40]. Furthermore, the translocation of $\mathrm{Cr}$ from the roots to the aerial shoots is very limited and it depends on the chemical form of $\mathrm{Cr}$ inside the tissue [4]. In plant tissues, the $\mathrm{Cr}$ (VI) is converted to $\mathrm{Cr}$ (III) that has the tendency to bind to the cell walls, which hinders the further transport of Cr within plant tissues [56].

Numerous metal transporter gene families including CDF (cation diffusion facilitator), HMA (heavy metal ATPase), ATP binding cassette (ABC) superfamily and ZIP (ZRT, IRT-like protein) have been identified for different metals like $\mathrm{Pb}, \mathrm{Cd}, \mathrm{Zn}$ and $\mathrm{As}$ [4,57-61]. However, the role of transporter families in the translocation of $\mathrm{Cr}$ in plants is still unclear. The translocation of $\mathrm{Cr}$ (VI) to shoots is an active process that involves phosphate and sulfate transporters [4]. Hence, the translocation of Cr might be mediated by iron (Fe) and sulfur (S) channels in the roots that lead to the competition 
between metals e.g., Fe and $\mathrm{Cr}[4,62]$. Cary et al. [63] had reported $\mathrm{Cr}$ uptake and translocation to the aerial shoots in Fe hyperaccumulators Brassica rapa and Spinacia oleracea signifying that $\mathrm{Cr}$ may be transported through Fe channels. However, the presence of $\mathrm{Fe}$ in the growth media reduced $\mathrm{Cr}$ translocation to the shoots [64], which could be due to the competition of carrier channels or due to the precipitation of Fe with Cr.

\section{Effect of Cr on Nutrient Uptake}

Heavy metal stress affects nutrient uptake in plants by interacting with other essential minerals. Chromium restricts the uptake of nutrients in soil by forming insoluble compounds [65]. Nutrient uptake is thereby inhibited by the metal toxicity especially when the concentration of the metal exceeds its permissible limits [66]. For instance, excessive $\mathrm{Cr}$ had been observed to reduce the uptake of essential minerals like iron $(\mathrm{Fe})$, magnesium $(\mathrm{Mg})$, phosphorus $(\mathrm{P})$ and calcium $(\mathrm{Ca})$ by masking the sorption sites and forming insoluble complexes [56,66]. However, $\mathrm{Cr}$ transport to different parts of Citrullus plants had increased leading to enhancement in the concentrations of manganese (Mn) and $\mathrm{P}$, and reduction in sulphur $(\mathrm{S})$, copper $(\mathrm{Cu})$, zinc $(\mathrm{Zn})$ and iron $(\mathrm{Fe})$ contents in the leaves, suggesting that $\mathrm{Cr}$ disturbs the nutrient balance [67]. Turner and Rust [68] also suggested the similar effects of Cr on the uptake of various nutrients under $\mathrm{Cr}$ toxicity. A gradual decrease in the uptake of micronutrients like $\mathrm{Zn}, \mathrm{Cu}, \mathrm{Fe}, \mathrm{Mn}$ and macronutrients like potassium $(\mathrm{K}), \mathrm{P}$ and nitrogen $(\mathrm{N})$ had been noticed in the paddy plants (Oryza sativa L.) under excessive Cr exposure [69]. This reduced nutrient uptake may occur due to decline in the root growth and impairment of the root penetration under $\mathrm{Cr}$ toxicity, or may be due to the decrease in essential element translocation because of the displacement of nutrients from the physiologically important binding sites [70,71].

\section{Effect of Cr on Chlorophyll Molecules and Photosynthetic Performance}

Foliar content of chlorophyll pigments including total chlorophyll, chlorophyll a (Chl a) and chlorophyll $b(\mathrm{Chl} \mathrm{b})$ were assayed under $\mathrm{Cr}$ treatment, which showed significant decrease in pigment accumulation of Catharanthus roseus plants [72]. This could be due to the inhibition of chlorophyll biosynthesis under $\mathrm{Cr}$ stress [73,74]. Increased concentration of $\mathrm{Cr}$ may lead to the deterioration of the chlorophyll content in many plants [75]. Plants exposed to Cr stress showed depleted chlorophyll contents that might be due to the disrupted chlorophyll biosynthesis [76]. Interestingly, an enzyme involved in chlorophyll biosynthesis, i.e., $\delta$-aminolevulinic acid dehydratase (ALAD) is being inhibited by $\mathrm{Cr}$ due to the impairment in utilizing the $\delta$-aminolevulinic acid [77].

Effect of $\mathrm{Cr}$ was also depicted on pigment contents viz. chlorophyll of vetiver [78] where alterations in the photosynthetic pigments were observed. $\mathrm{Cr}$ induced toxicity had been reported to decrease the chlorophyll contents in different plants species such as Pistia stratiotes [79], Citrus limonia and Citrus reshni [80], Zea mays [81,82], Hibiscus esculantus [83], Camellia sinensis [84], Glycine max [85] and Ocimum tenuiflorum [31]. Decrease in chlorophyll contents under $\mathrm{Cr}$ toxicity could be due to the impairment of chlorophyll biosynthesis enzymes, which are compromised under Cr toxicity $[86,87]$. Degradation of ALAD could occur under Cr toxicity leading to a decrease in chlorophyll level [88]. Hence, photosynthetic capacity of plants is compromised under $\mathrm{Cr}$ stress due to interaction with biosynthesis of chlorophyll molecules by inhibiting vital enzymes contributing in photosynthesis. Excessive $\mathrm{Cr}$ affects photosynthetic system by targeting the Calvin cycle enzymes, photosynthetic electron transport and thylakoid membrane [89]. Therefore, gradual decrease in the net photosynthetic rate can be observed in the plants treated with higher concentration of $\mathrm{Cr}$ [90].

Changes in the level of photosynthetic pigments give an important information regarding the toxic effects of heavy metals, e.g., $\mathrm{Cr}, \mathrm{Ni}, \mathrm{Pb}$ and $\mathrm{Cd}[70,74,91-94]$. However, reduced chlorophyll contents may be observed due to the increased activity of enzymes like chlorophyllase and deficiency of nutrients, i.e., because of the translocation of the metals to shoots in higher concentration [91,95]. Moreover, a significant decrease in transpiration rate, net photosynthetic rate, intercellular $\mathrm{CO}_{2}$ concentration and stomatal conductance in the leaves were observed where $\mathrm{Cr}$ toxicity reduced these parameters by $71 \%$, 
$36 \%, 25 \%$ and $57 \%$ respectively [96]. Cr also poses hazardous effects on gas exchange as shown by the multiple linear regression (MLR) analysis that expressed negative $\beta$-regression coefficients for all the parameters of gas exchange [97]. Davies Jr et al. [96] had noticed that $\mathrm{Cr}$ inhibited photosynthetic process by targeting photosystem II (PSII). Hence, chlorophyll fluorescence seems quite useful tool to study photosynthetic apparatus and action of PSII under heavy metal stress.

\section{Reactive Oxygen Species (ROS) and Oxidative Stress}

A rather common and frequent effect of heavy metal stress is the overproduction of ROS including hydroxyl radicals $\left(\mathrm{OH}^{-}\right)$, hydroperoxyl radicals $(\mathrm{HOO})$, superoxide $\left(\mathrm{O}_{2}^{-}\right)$, the peroxinitrite $\left(\mathrm{OONO}^{-}\right)$ ion, the paramagnetic singlet oxygen $\left({ }^{1} \mathrm{O}_{2}\right)$, nitrogen oxide radical $(\mathrm{NO})$, hydrogen peroxide $\left(\mathrm{H}_{2} \mathrm{O}_{2}\right)$, ozone $\left(\mathrm{O}_{3}\right)$ and hypochlorous acid $(\mathrm{HOCl})$ molecules [98-101]. This process is considered as one of the primary cause for the alterations in plant biology at biochemical level under heavy metal toxicity $[70,73,74,102-106]$. Plants may suffer through various drastic physiological changes, which are mainly due to the imbalance in the generation and scavenging of ROS, termed as an oxidative burst $[70,74,94,102,104,107-112]$. Heavy metals like copper $(\mathrm{Cu})$, nickel (Ni), cadmium (Cd), $\mathrm{Cr}$ and arsenic (As) have the tendency to generate ROS if they exceed permissible limits [70,113-115].

On the basis of physical and biochemical characteristics of bioactive-metals, these metals can be classified into two groups; redox metals like $\mathrm{Cr}, \mathrm{Cu}, \mathrm{Fe}$ and non-redox metals like $\mathrm{Cd}, \mathrm{Hg}, \mathrm{Ni}, \mathrm{Zn}$, etc. Redox active metals have the capacity to produce oxidative injuries in plants via Haber-Weiss and Fenton reactions, that consequently generate ROS and leading to disturb the balance between prooxidant and antioxidant level [116]. However, redox-inactive metals form covalent bonds with the protein sulfhydryl groups as these metals have the tendency of sharing the electrons.

When $\mathrm{Cr}$ metal interacts with the proteins at its catalytic site or any other site, it deactivates the active sites of enzymes by binding specific functional groups of proteins, thus leading to the alteration of enzymatic activities $[117,118]$. Furthermore, dislocation of critical cations from the specific enzyme binding sites disturbs the equilibrium of ROS in cells, and as a consequence ROS are generated in drastic amount [119]. Chromium metal has also tendency to bind and utilize the reduced form of glutathione (GSH) and its derivatives, which plays a significant role in ameliorating these ROS [120]. Besides, NADPH oxidase (present on plasma membrane) also leads to oxidative stress as they are linked with the $\mathrm{Cr}$ [121-123]. In the presence of $\mathrm{Cr}$ metal, the NADPH oxidases may consume cytosolic NADPH and produce free radical $\mathrm{O}_{2}{ }^{-}$, which is rapidly converted to $\mathrm{H}_{2} \mathrm{O}_{2}$ by superoxide dismutase enzyme (SOD) [124]. Free radicals generated by $\mathrm{Cr}$ in association with NADPH oxidase remains outside the plasma membrane, where $\mathrm{pH}$ remains usually low in comparison to inner side of the cell [125]. Reports suggest that the enhanced generation of ROS in plants under Cr toxicity leads to oxidative burst by causing damage to DNA, lipids, pigments, proteins and stimulates the process of lipid peroxidation (Figure 1) [126,127]. Carrier membrane stimulates the absorption of $\mathrm{Cr}$ and over productions of ROS further influences the plasma membrane [41].

There are several reports documented where drastic increase in ROS was observed $[22,74,104,128]$ with increased malondialdehyde (MDA) contents under Cr toxicity [129]. Alterations in different physiological and biochemical activities have been observed in Triticum aestivum, Vallisneria spiralis and Ocimum tenuiflorum $[22,31,88]$ where $\mathrm{Cr}$ metal stimulated the deterioration of membrane permeability by generating MDA. Similarly, increased levels of MDA were found in both roots and leaves of Kandelia candel (L.) plants in a dose dependent manner suggesting its gradual uptake under a timely manner [30]. 


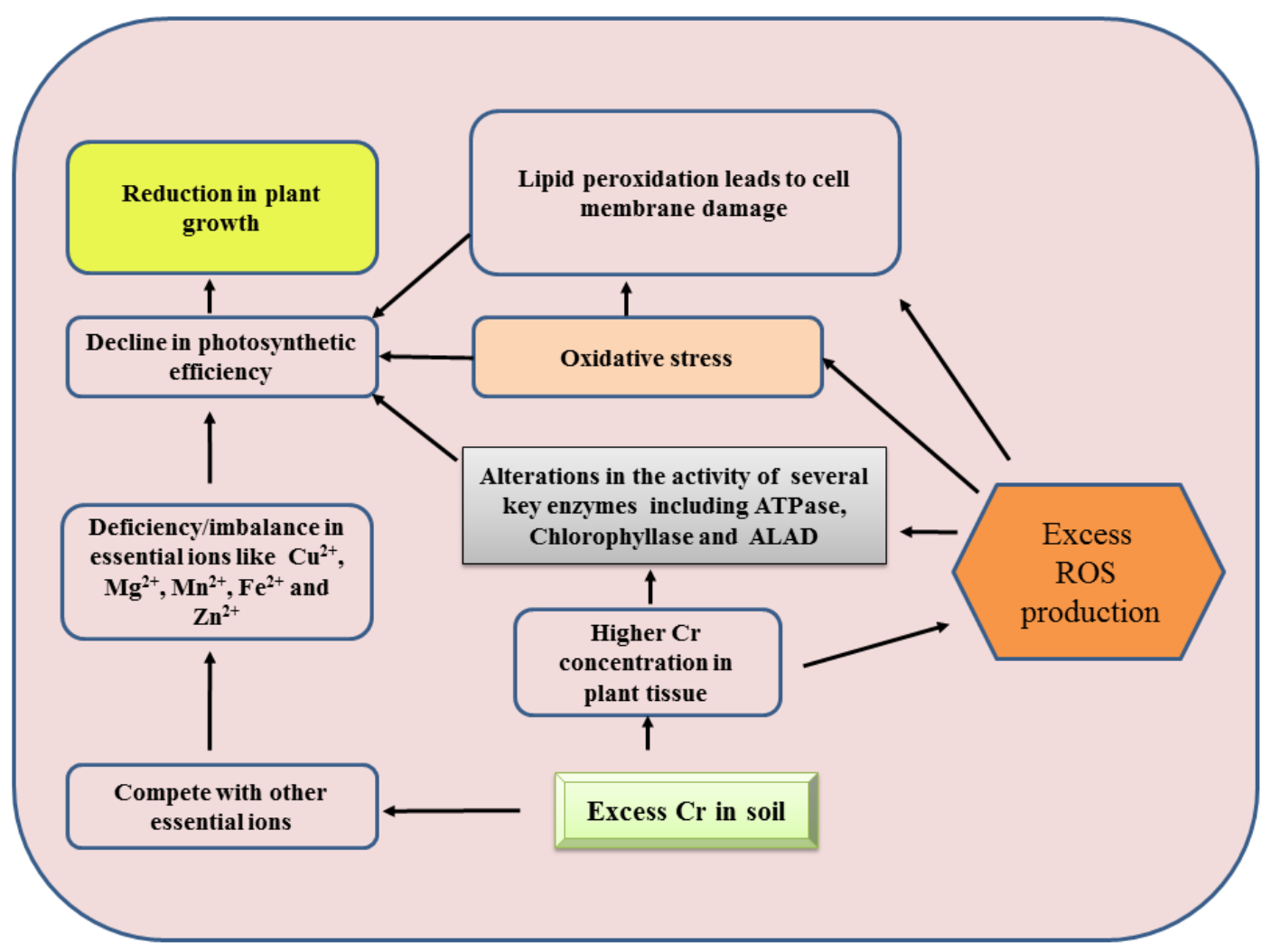

Figure 1. Consequences of oxidative stress generated under chromium toxicity.

\section{Effect of Cr on Enzymatic Antioxidative System}

Activities of various antioxidative enzymes drastically change in plants when subject to $\mathrm{Cr}$ toxicity. ROS leads to oxidative stress, which may affect different subcellular compartments sensitive to ROS. Superoxide dismutase (SOD) is considered as a first line of defense against various stresses in almost all the aerobic organisms [70,130]. Dismutation of superoxide ion is catalyzed by the SOD enzyme, which is localized in almost all the cellular compartments, leading to the production of hydrogen peroxide and release of oxygen [130]. SOD is involved in the Asada-Halliwell cycle in chloroplasts and also present in cytosol, apoplasts, mitochondria and peroxisomes [131]. For the removal of ROS, catalase (CAT) enzyme also plays crucial role, hence considered as important antioxidant enzyme [132]. Dismutation of $\mathrm{H}_{2} \mathrm{O}_{2}$ into $\mathrm{O}_{2}$ and $\mathrm{H}_{2} \mathrm{O}$ is undergone by this enzyme [133].

When exposed to $\mathrm{Cr}$ (III) stress for seven days, chamomile plants showed increased accumulation of $\mathrm{Cr}$ mainly in the roots of the plants, which contained high concentrations of ROS, nitric oxide and thiols. At higher concentration of $\mathrm{Cr}$ (III), SOD activity specifically was increased in the roots, while level of $\mathrm{H}_{2} \mathrm{O}_{2}$ showed irregular trend under different concentrations of $\mathrm{Cr}$ due to the altered activities of various peroxidases [28]. Different concentrations of $\mathrm{Cr}(\mathrm{VI})\left(50,100,200\right.$ and $300 \mu \mathrm{M} \mathrm{L}^{-1}$ ) escalated the production of $\mathrm{H}_{2} \mathrm{O}_{2}$ leading to the lipid peroxidation and triggered the activities of antioxidative enzymes like SOD and guaiacol peroxidase (GPX) in comparison to control plants [41]. In contrast, activities of peroxidase (POD), SOD and CAT were decreased when subjected to $\mathrm{Cr}$ (III) in a dose dependent manner [26].

Maintaining metabolic functions under stress conditions is crucial for plants to survive. Therefore, a balance between generation and scavenging of ROS is required, which is achieved by regulating the production of enzymatic and non-enzymatic antioxidants [134]. Hence, the ability of plants to cope with oxidative stress is characterized by the degree of antioxidant activities [102,104]. However, activities of these antioxidants may vary with the duration, crop species and tissues under any stress condition [135]. For instance, Echinochloa colona plants showed increased activities of POD and CAT in tolerant calluses in comparison to non-tolerant ones [29]. At $0.5 \mathrm{mg} \mathrm{L}^{-1}$ concentration of $\mathrm{Cr}$ (VI), CAT 
activity was increased, however decreased at higher concentrations $\left(1.0-2.0 \mathrm{mg} \mathrm{L}^{-1}\right)$. Activity of CAT was measured highest at $2.0 \mathrm{mg} \mathrm{L}^{-1}$ concentration of $\mathrm{Cr}$ in the roots of $\mathrm{K}$. candel but decreased at higher concentration [30]. As CAT is an iron-porphyrine biomolecule, reduction in CAT activity indicates that $\mathrm{Cr}$ has the potential to interact with iron in metabolic pool or it may influence the presence of active form of iron [136]. Cr toxicity has detrimental effects on antioxidant enzymes such as POD, GPX, glutathione reductase (GR) and ascorbate peroxidase (APX), hence resulting in the inhibition of enzyme activities $[129,137]$. Plants equipped with an efficient antioxidant system are more capable to withstand and tolerate higher $\mathrm{Cr}$ concentrations. Failure to do so results in the breakdown of the plant defense system hence activities of antioxidants are jeopardized leading to reduced plant growth or even leading to plant death.

\section{Effect of Cr on Non-Enzymatic Antioxidative System}

Apart from the enzymatic antioxidants, plants are also comprised of a complex non-enzymatic antioxidant defense system to avoid the toxic effects of ROS. These non-enzymatic antioxidants consist of low molecular weight molecules such as ascorbic acid, glutathione (GSH), phenolic acids, carotenoids, flavonoids, etc. [94,138] and some high molecular weight secondary metabolites such as tannins [139]. Biosynthesis and accumulation of these non-enzymatic antioxidants by plants could be due to two main reasons. First, plants have an innate ability to synthesize a variety of phytochemicals to carry out their normal physiological functioning or to protect them from any pathogenic or herbivores. Second, plants also synthesize phytochemicals to respond to the environmental factors which could be due to their natural tendency of defense against any biotic and abiotic stress [140]. Therefore, these lower molecular weight antioxidants are synthesized and act as a redox buffer to interact with cellular components and directly influence plant growth and development by modulating different processes from mitosis to cell elongation and to senescence. Hence, it is crucial for plants to synthesize these antioxidants under stressed conditions. Glutathione is a redoxactive molecule that can be present in a reduced form GSH or an oxidized form GSSG. It plays important roles in the plant defensive system including biosynthetic pathways, detoxification, antioxidant biochemistry and redox homeostasis $[141,142]$. GSH acts as an antioxidant by quenching ROS and is involved in the ascorbate-glutathione cycle, which eliminates damaging peroxides [143]. In poplar trees, glutathione (GSH) biosynthesis was stimulated under $\mathrm{Cr}$ toxicity [144]. In the leaf extracts of tomato (Lycopersicon esculentum), maize (Zea mays) and cauliflower (Brassica oleracea) plants, GSH level increased subjected to Cr toxicity [145]. Alterations were observed in the glutathione pool dynamics where individual level of GSSG and GSH and GSH/GSSG ratio was affected, however sorghum (Sorghum biclor) plants showed potential to scavenge the free radicals generated under Cr toxicity [146].

Under sub-optimal conditions, level of antioxidants may decrease or increase depending on the severity of stress. For instance, a sharp decline in the GSH pool was observed under Cr stress, which severely affected the roots of the plants. Many reports suggested the oxidation of various cellular thiols like GSH and cysteine in plants subjected to $\mathrm{Cr}$ (VI) stress in in vitro conditions [147]. Therefore, to maintain the redox homeostasis of the cell and for scavenging of free radicals, the interconversion of reduced and oxidized forms of glutathione (GSH and GSSG respectively) is required.

A non-enzymatic antioxidant "carotenoid" contributes in providing protection to the chlorophylls against stress conditions by replacing peroxides and scavenging of photodynamic reactions [148]. For instance, carotenoid level increased in Capsicum annuum plants subjected to industrial effluents specifically containing $\mathrm{Cr}$ [27], acting as a defensive mechanism for capsicum plants to scavenge the free radicals. Other non-enzymatic antioxidants such as cysteine, proline, nonprotein thiol, etc. may also contribute in modulating resistance against $\mathrm{Cr}$ toxicity and protect the macromolecules from the free radicals generated during the oxidative burst [77]. In one of the reports, carotenoids, non-protein thiol (NP-SH) and cysteine level increased in the plants subjected to $\mathrm{Cr}$ [72].

For providing protection against different types of stresses, accumulation of compatible osmolytes like proline (Pro) occurs in most of the plants for providing membrane stability and osmotic 
adjustment [94,149]. Proline contents can increase against different types of biotic and abiotic stresses such as salinity, drought, temperature, heavy metal and pathogen attack [77]. For instance, contents of Pro increased in Ocimum tenuiflorum L. under Cr stress, which acted as an antioxidant by providing protection against the hazardous effects of metal [31]. Reports suggested that proline is the only amino acid that accumulates in the leaves of plants under stress conditions [150]. It starts accumulating even at low doses of stress and increases in a dose dependent manner. Hence, accumulation of proline contributes to osmotic adjustment when it gets accumulated in tissues and acts as a dependent marker for genotypes for the stress tolerance [150]. Polyamines are other non-enzymatic osmoprotectants, which increase under different abiotic stress conditions [151], and also associated with the boosting up of plant defensive mechanisms [92,152]. Polyamines including putrescine, spermine and spermidine have been investigated to increase $\mathrm{Cr}$ tolerance in plants under $\mathrm{Cr}$ toxicity [38].

\section{Effect of Cr on the Endogenous Levels of Plant Hormones}

Plant hormones control and regulate plant growth and development through different biochemical and physiological process. These hormones may act either close to or remote from their synthesis site to regulate responses to environmental stimuli or genetically programmed developmental changes [153]. Hormones thus have a vital role in plant adaptation to abiotic stress, from which the plant may attempt to escape or survive under stressful conditions [154]. Thus, abiotic stresses often alter the production, distribution or signal transduction of growth as well as stress hormones, which may promote specific protective mechanisms. The phytohormone abscisic acid (ABA) plays a vital role against abiotic stresses, thus it is considered as a stress hormone. Under different types of abiotic stress conditions, endogenous level of ABA are increased drastically in plants, which boosts up the signaling pathways and activates expression of ABA-responsive genes [155]. For instance, strong expression of ABA biosynthesis genes (OsNCED2 and OsNCED3) and four ABA signaling genes were upregulated in response to heavy metal stress [156]. Salicylic acid (SA) also provides protection under $\mathrm{Cr}$ stress. SA plays a significant positive role in growth and development of plants as well as ripening and abiotic stress tolerance [157]. Interaction of ABA and SA also contributes in boosting the defensive strategies of plants against $\mathrm{Cr}$ toxicity [158]. Apart from this, SA also plays essential role in combination with jasmonic acid (JA) and ethylene, where the interaction of these hormones provides tolerance against $\mathrm{Cr}$ stress $[159,160]$. The biosynthesis, transportation and accumulation of these plant hormones boost the signaling pathways, activating certain antioxidant gene expressions and stimulating the production of osmoprotectants such as proline, soluble sugars, amino acids, etc. [161].

Indole acetic acid (IAA), a plant hormone of auxins contributes to the growth and development of plants under ideal as well as stressed conditions [162]. IAA plays a key role in plant adaptation to heavy metal stress by either increasing the membrane permeability or by increasing the concentration of osmotically active solutes [16,163]. The level of IAA usually increases in the plants under metal toxicity by affecting different metabolic activities of plants including growth and hormonal balance [164]. Gibberellins (GAs) are considered as comprehensive class of tetracyclic diterpenoid carboxylic acid compounds. Different forms of GAs have potential to play the role of growth hormone in higher plants such as GA1 and GA3 [165]. Generally, at low concentration of metal like $\mathrm{Cr}$ leads to the elevated level of GA3, although its high concentration reduces the GA3 content [166]. Apart from these, plant hormone like cytokinins (CKs), contributes in the regulation of plant development by stimulating cell division and elongation. Cr stress alters endogenous level of CKs suggesting that CKs are also involved in tolerating the stress [155]. A few reports also indicated the reduction in the synthesis of CKs and their transport from roots to other aerial parts of plants during $\mathrm{Cr}$ toxicity and they are also found to interact with other plant hormones [167].

\section{Conclusions and Prospects}

This review illustrates an overview of $\mathrm{Cr}$ metal effects on plant growth and development. Plants uptake $\mathrm{Cr}$ via roots, which causes nutrient imbalance, root injury as well as leaf chlorosis. $\mathrm{Cr}$ toxicity 
also targets chlorophyll biosynthesis by inhibiting the activity of vital enzymes. Additionally, it also results in oxidative stress by targeting cellular membranes and biomolecules resulting in retarded plant growth, induction of chlorosis and wilting of leaves. Although a handful of data is available that provides useful information to understand chromium interaction with other essential metal ions. The mechanisms generating $\mathrm{Cr}$-induced toxicity at the protein and molecular level still need to be explored in detail. Furthermore, exploration of $\mathrm{Cr}$ tolerance mechanism and homeostasis are essential for sustainable crop production, which is poorly understood in many ecosystems. Therefore, it is essential to understand the possible means to reduce $\mathrm{Cr}$ uptake and its negative impacts on environment especially in plants.

Author Contributions: A.S., design of outline, wrote abstract, Sections 1 and 5 and revised initial draft; D.K., J.W., wrote Sections 2, 4 and 6; B.S., V.K., A.S.B. and S.J. wrote Sections 3, 7 and 8; B.Z., D.Y. and H.Y., were involved in designing outline, revision of initial draft and arranging resources. All authors have read and agreed to the published version of the manuscript.

Funding: We acknowledge the different funding agencies: This study was supported by National Key Research and Development Program of China (2018YFD1000600, 2018YFD1000604); Key Project of Zhejiang Provincial Natural Science Foundation (LZ18C160001); National Natural Science Foundation of China $(31,901,346$, 31,971,695, 31,470,683, 31,270,716 and 31,070,604); Independent Research Project of State Key Laboratory of Subtropical Silviculture, Zhejiang A\&F University (ZY20180208, ZY20180308); Open Foundation of State Key Laboratory of Subtropical Silviculture, Zhejiang A\&F University (KF201708); Overseas Expertise Introduction Project for Discipline Innovation (111 Project D18008); Key Research and Development Program of Zhejiang Province (2018C02004); National High Technology Research and Development Program of China (863 Program) (2013AA102605); Fruit Innovation Team Project of Zhejiang Province (2016C02052-12); Key Agricultural New Varieties Breeding Projects founded by Zhejiang Province Science and Technology Department (2016C02052-13); Zhejiang Provincial Natural Science Foundation for Distinguished Young Scholar (LR13C160001); Open Foundation of First-class Discipline of Forestry, Zhejiang Province (201703); The First-class General Financial Grant from the China Postdoctoral Science Foundation (2017M610377).

Conflicts of Interest: The authors declare no conflict of interest.

\section{References}

1. Nriagu, J.O.; Pacyna, J.; Milford, J.B.; Davidson, C.I. Distribution and characteristic features of chromium in the atmosphere. In Chromium in Natural and Human Environments; Wiley Interscience: New York, NY, USA, 1988; pp. 125-173.

2. CERCLA Priority List of Hazardous Substances. Agency for Toxic Substances and Disease Registry, USA. 2017. Available online: https://www.atsdr.cdc.gov/spl/ (accessed on 20 September 2019).

3. International Agency for Research on Cancer. Overall evaluations of carcinogenicity: And updating of IARC monographs, vol. 1 to 42 . IARC monographs on the evaluation of the carcinogenic risk of chemicals to humans: Suppl 7. IARC 1987, 7, 1-440.

4. Shahid, M.; Shamshad, S.; Rafiq, M.; Khalid, S.; Bibi, I.; Niazi, N.K.; Dumat, C.; Rashid, M.I. Chromium speciation, bioavailability, uptake, toxicity and detoxification in soil-plant system: A review. Chemosphere 2017, 178, 513-533. [CrossRef] [PubMed]

5. Prado, C.; Chocobar Ponce, S.; Pagano, E.; Prado, F.E.; Rosa, M. Differential physiological responses of two Salvinia species to hexavalent chromium at a glance. Aquat. Toxicol. 2016, 175, 213-221. [CrossRef] [PubMed]

6. Ashraf, A.; Bibi, I.; Niazi, N.K.; Ok, Y.S.; Murtaza, G.; Shahid, M.; Kunhikrishnan, A.; Li, D.; Mahmood, T. Chromium (VI) sorption efficiency of acid-activated banana peel over organo-montmorillonite in aqueous solutions. Int. J. Phytoremediation 2017, 19, 605-613. [CrossRef] [PubMed]

7. Ertani, A.; Mietto, A.; Borin, M.; Nardi, S. Chromium in agricultural soils and crops: A review. Water Air Soil Pollut. 2017, 228, 190. [CrossRef]

8. Tchounwou, P.B.; Yedjou, C.G.; Patlolla, A.K.; Sutton, D.J. Heavy metal toxicity and the environment. In Molecular, Clinical and Environmental Toxicology; Springer: Berlin/Heidelberg, Germany, 2012; pp. 133-164.

9. Stambulska, U.Y.; Bayliak, M.M.; Lushchak, V.I. Chromium (VI) toxicity in legume plants: Modulation effects of rhizobial symbiosis. BioMed Res. Int. 2018, 2018, 1-13. [CrossRef]

10. Joutey, N.T.; Sayel, H.; Bahafid, W.; El Ghachtouli, N. Mechanisms of hexavalent chromium resistance and removal by microorganisms. In Reviews of Environmental Contamination and Toxicology; Springer: Berlin/Heidelberg, Germany, 2015; Volume 233, pp. 45-69. 
11. Kumar, V.; Parihar, R.D.; Sharma, A.; Bakshi, P.; Sidhu, G.P.S.; Bali, A.S.; Karaouzas, I.; Bhardwaj, R.; Thukral, A.K.; Gyasi-Agyei, Y. Global evaluation of heavy metal content in surface water bodies: A meta-analysis using heavy metal pollution indices and multivariate statistical analyses. Chemosphere 2019, 236, 124364. [CrossRef]

12. Kumar, V.; Sharma, A.; Kaur, P.; Sidhu, G.P.S.; Bali, A.S.; Bhardwaj, R.; Thukral, A.K.; Cerda, A. Pollution assessment of heavy metals in soils of India and ecological risk assessment: A state-of-the-art. Chemosphere 2019, 216, 449-462. [CrossRef]

13. Environmental Protection Agency. Effluent Limitations Guidelines, Pretreatment Standards, and New Source Performance Standards for the Commercial Hazardous Waste Combustor Subcategory of the Waste Combustors Point Source Category. Fed. Regist. 2000, 00-2019, 4360-4385.

14. World Health Organization. Air Quality Guidelines for Europe, 2000; WHO Regional Office for Europe: Copenhagen, Denmark, 2000.

15. Reale, L.; Ferranti, F.; Mantilacci, S.; Corboli, M.; Aversa, S.; Landucci, F.; Baldisserotto, C.; Ferroni, L.; Pancaldi, S.; Venanzoni, R. Cyto-histological and morpho-physiological responses of common duckweed (Lemna minor L.) to chromium. Chemosphere 2016, 145, 98-105. [CrossRef]

16. UdDin, I.; Bano, A.; Masood, S. Chromium toxicity tolerance of Solanum nigrum L. and Parthenium hysterophorus L. plants with reference to ion pattern, antioxidation activity and root exudation. Ecotoxicol. Environ. Saf. 2015, 113, 271-278. [CrossRef] [PubMed]

17. Kamran, M.; Eqani, S.; Katsoyiannis, A.; Xu, R.; Bibi, S.; Benizri, E.; Chaudhary, H. Phytoextraction of chromium (Cr) and influence of Pseudomonas putida on Eruca sativa growth. J. Geochem. Explor. 2017, 182, 269-274. [CrossRef]

18. Santos, C.; Rodriguez, E. Review on some emerging endpoints of chromium (VI) and lead phytotoxicity. In Botany; InTech: Rijeka, Croatia, 2012; pp. 61-82.

19. Eleftheriou, E.; Adamakis, I.-D.; Panteris, E.; Fatsiou, M. Chromium-induced ultrastructural changes and oxidative stress in roots of Arabidopsis thaliana. Int. J. Mol. Sci. 2015, 16, 15852-15871. [CrossRef] [PubMed]

20. Kumari, V.; Yadav, A.; Haq, I.; Kumar, S.; Bharagava, R.N.; Singh, S.K.; Raj, A. Genotoxicity evaluation of tannery effluent treated with newly isolated hexavalent chromium reducing Bacillus cereus. J. Environ. Manag. 2016, 183, 204-211. [CrossRef]

21. Shanker, A.K.; Djanaguiraman, M.; Venkateswarlu, B. Chromium interactions in plants: Current status and future strategies. Metallomics 2009, 1, 375-383. [CrossRef] [PubMed]

22. Ali, S.; Bharwana, S.A.; Rizwan, M.; Farid, M.; Kanwal, S.; Ali, Q.; Ibrahim, M.; Gill, R.A.; Khan, M.D. Fulvic acid mediates chromium (Cr) tolerance in wheat (Triticum aestivum L.) through lowering of $\mathrm{Cr}$ uptake and improved antioxidant defense system. Environ. Sci. Pollut. Res. 2015, 22, 10601-10609. [CrossRef]

23. Farooq, M.; Ali, S.; Hameed, A.; Bharwana, S.; Rizwan, M.; Ishaque, W.; Farid, M.; Mahmood, K.; Iqbal, Z. Cadmium stress in cotton seedlings: Physiological, photosynthesis and oxidative damages alleviated by glycinebetaine. S. Afr. J. Bot. 2016, 104, 61-68. [CrossRef]

24. Cervantes, C.; Campos-García, J. Reduction and efflux of chromate by bacteria. In Molecular Microbiology of Heavy Metals; Springer: Berlin/Heidelberg, Germany, 2007; pp. 407-419.

25. Anjum, S.A.; Ashraf, U.; Khan, I.; Tanveer, M.; Shahid, M.; Shakoor, A.; Wang, L. Phyto-toxicity of chromium in maize: Oxidative damage, osmolyte accumulation, anti-oxidative defense and chromium uptake. Pedosphere 2017, 27, 262-273. [CrossRef]

26. Tang, M.; Mao, D.; Xu, L.; Li, D.; Song, S.; Chen, C. Integrated analysis of miRNA and mRNA expression profiles in response to Cd exposure in rice seedlings. BMC Genom. 2014, 15, 835. [CrossRef]

27. Oliveira, H. Chromium as an environmental pollutant: Insights on induced plant toxicity. J. Bot. 2012, 2012, 1-8. [CrossRef]

28. Kováčik, J.; Babula, P.; Klejdus, B.I.; Hedbavny, J. Chromium uptake and consequences for metabolism and oxidative stress in chamomile plants. J. Agric. Food Chem. 2013, 61, 7864-7873. [CrossRef] [PubMed]

29. Samantaray, S.; Rout, G.R.; Das, P. Induction, selection and characterization of Cr and Ni-tolerant cell lines of Echinochloa colona (L.) Link in vitro. J. Plant Physiol. 2001, 158, 1281-1290. [CrossRef]

30. Rahman, M.M.; Rahman, M.M.; Islam, K.S.; Chongling, Y. Effect of Chromium Stress on Antioxidative Enzymes and Malondialdehyde Content Activities in Leaves and Roots of Mangrove Seedlings Kandelia candel (L.) Druce. J. For. Environ. Sci. 2010, 26, 171-179. 
31. Rai, V.; Vajpayee, P.; Singh, S.N.; Mehrotra, S. Effect of chromium accumulation on photosynthetic pigments, oxidative stress defense system, nitrate reduction, proline level and eugenol content of Ocimum tenuiflorum L. Plant Sci. 2004, 167, 1159-1169. [CrossRef]

32. Ma, J.; Lv, C.; Xu, M.; Chen, G.; Lv, C.; Gao, Z. Photosynthesis performance, antioxidant enzymes, and ultrastructural analyses of rice seedlings under chromium stress. Environ. Sci. Pollut. Res. 2016, 23, 1768-1778. [CrossRef] [PubMed]

33. Trinh, N.N.; Huang, T.L.; Chi, W.C.; Fu, S.F.; Chen, C.C.; Huang, H.J. Chromium stress response effect on signal transduction and expression of signaling genes in rice. Physiol. Plant. 2014, 150, 205-224. [CrossRef]

34. Zhang, X.; Zhang, S.; Xu, X.; Li, T.; Gong, G.; Jia, Y.; Li, Y.; Deng, L. Tolerance and accumulation characteristics of cadmium in Amaranthus hybridus L. J. Hazard. Mater. 2010, 180, 303-308. [CrossRef]

35. Xu, L.; Han, L.; Huang, B. Membrane fatty acid composition and saturation levels associated with leaf dehydration tolerance and post-drought rehydration in Kentucky bluegrass. Crop Sci. 2011, 51, $273-281$. [CrossRef]

36. Aldoobie, N.; Beltagi, M. Physiological, biochemical and molecular responses of common bean (Phaseolus vulgaris L.) plants to heavy metals stress. Afr. J. Biotechnol. 2013, 12, 4614-4622. [CrossRef]

37. Duhan, J.S. Chromium stress on peroxidase, ascorbate peroxidase and acid invertase in pea (Pisum sativum L.) seedling. Int. J. Biotechnol. Mol. Biol. Res. 2012, 3, 15-21.

38. Paiva, L.B.; Correa, S.F.; Santa Catarina, C.; Floh, E.I.S.; Silva, M.G.D.; Vitória, A.P. Ecophysiological and biochemical parameters for assessing $\mathrm{Cr}^{+6}$ stress conditions in Pterogyne nitens Tul.: New and usual methods for the management and restoration of degraded areas. Environ. Eng. Manag. J. 2014, 13, 3073-3081. [CrossRef]

39. Choudhary, S.P.; Kanwar, M.; Bhardwaj, R.; Yu, J.-Q.; Tran, L.-S.P. Chromium stress mitigation by polyamine-brassinosteroid application involves phytohormonal and physiological strategies in Raphanus sativus L. PLoS ONE 2012, 7, e33210. [CrossRef] [PubMed]

40. Shanker, A.K.; Djanaguiraman, M.; Sudhagar, R.; Chandrashekar, C.; Pathmanabhan, G. Differential antioxidative response of ascorbate glutathione pathway enzymes and metabolites to chromium speciation stress in green gram (Vigna radiata (L.) R. Wilczek. cv CO 4) roots. Plant Sci. 2004, 166, 1035-1043. [CrossRef]

41. Maiti, S.; Ghosh, N.; Mandal, C.; Das, K.; Dey, N.; Adak, M.K. Responses of the maize plant to chromium stress with reference to antioxidation activity. Braz. J. Plant Physiol. 2012, 24, 203-212. [CrossRef]

42. Khanna, K.; Jamwal, V.L.; Sharma, A.; Gandhi, S.G.; Ohri, P.; Bhardwaj, R.; Al-Huqail, A.A.; Siddiqui, M.H.; Ali, H.M.; Ahmad, P. Supplementation with plant growth promoting rhizobacteria (PGPR) alleviates cadmium toxicity in Solanum lycopersicum by modulating the expression of secondary metabolites. Chemosphere 2019, 230, 628-639. [CrossRef] [PubMed]

43. Kaur, R.; Yadav, P.; Sharma, A.; Thukral, A.K.; Kumar, V.; Kohli, S.K.; Bhardwaj, R. Castasterone and citric acid treatment restores photosynthetic attributes in Brassica juncea L. under Cd (II) toxicity. Ecotoxicol. Environ. Saf. 2017, 145, 466-475. [CrossRef]

44. Kaur, R.; Yadav, P.; Thukral, A.K.; Sharma, A.; Bhardwaj, R.; Alyemeni, M.N.; Wijaya, L.; Ahmad, P. Castasterone and citric acid supplementation alleviates cadmium toxicity by modifying antioxidants and organic acids in Brassica juncea. J. Plant Growth Regul. 2018, 37, 286-299. [CrossRef]

45. Kohli, S.K.; Handa, N.; Sharma, A.; Gautam, V.; Arora, S.; Bhardwaj, R.; Alyemeni, M.N.; Wijaya, L.; Ahmad, P. Combined effect of 24-epibrassinolide and salicylic acid mitigates lead $(\mathrm{Pb})$ toxicity by modulating various metabolites in Brassica juncea L. seedlings. Protoplasma 2018, 255, 11-24. [CrossRef]

46. Srivastava, S.; Srivastava, S.; Prakash, S.; Srivastava, M. Fate of trivalent chromium in presence of organic acids: A hydroponic study on the tomato plant. Chem. Speciat. Bioavailab. 1998, 10, 147-150. [CrossRef]

47. Skeffington, R.; Shewry, P.; Peterson, P. Chromium uptake and transport in barley seedlings (Hordeum vulgare L.). Planta 1976, 132, 209-214. [CrossRef]

48. Shanker, A.K.; Cervantes, C.; Loza-Tavera, H.; Avudainayagam, S. Chromium toxicity in plants. Environ. Int. 2005, 31, 739-753. [CrossRef] [PubMed]

49. Cervantes, C.; Campos-García, J.; Devars, S.; Gutiérrez-Corona, F.; Loza-Tavera, H.; Torres-Guzmán, J.C.; Moreno-Sánchez, R. Interactions of chromium with microorganisms and plants. FEMS Microbiol. Rev. 2001, 25, 335-347. [CrossRef] [PubMed]

50. Appenroth, K.J.; Luther, A.; Jetschke, G.; Gabrys, H. Modification of chromate toxicity by sulphate in duckweeds (Lemnaceae). Aquat. Toxicol. 2008, 89, 167-171. [CrossRef] [PubMed] 
51. De Oliveira, L.M.; Ma, L.Q.; Santos, J.A.; Guilherme, L.R.; Lessl, J.T. Effects of arsenate, chromate, and sulfate on arsenic and chromium uptake and translocation by arsenic hyperaccumulator Pteris vittata L. Environ. Pollut. 2014, 184, 187-192. [CrossRef] [PubMed]

52. De Oliveira, L.M.; Gress, J.; De, J.; Rathinasabapathi, B.; Marchi, G.; Chen, Y.; Ma, L.Q. Sulfate and chromate increased each other's uptake and translocation in As-hyperaccumulator Pteris vittata. Chemosphere 2016, 147, 36-43. [CrossRef] [PubMed]

53. Gupta, A.K.; Sinha, S. Chemical fractionation and heavy metal accumulation in the plant of Sesamum indicum (L.) var. T55 grown on soil amended with tannery sludge: Selection of single extractants. Chemosphere 2006, 64, 161-173. [CrossRef]

54. Caldelas, C.; Bort, J.; Febrero, A. Ultrastructure and subcellular distribution of Cr in Iris pseudacorus L. using TEM and X-ray microanalysis. Cell Biol. Toxicol. 2012, 28, 57-68. [CrossRef]

55. Mangabeira, P.A.; Ferreira, A.S.; de Almeida, A.-A.F.; Fernandes, V.F.; Lucena, E.; Souza, V.L.; dos Santos Júnior, A.J.; Oliveira, A.H.; Grenier-Loustalot, M.F.; Barbier, F. Compartmentalization and ultrastructural alterations induced by chromium in aquatic macrophytes. Biometals 2011, 24, 1017-1026. [CrossRef]

56. Kabata-Pendias, A.; Szteke, B. Trace Elements in Abiotic and Biotic Environments; CRC Press: Boca Raton, FL, USA, 2015.

57. Assuncao, A.G.; Herrero, E.; Lin, Y.F.; Huettel, B.; Talukdar, S.; Smaczniak, C.; Immink, R.G.; van Eldik, M.; Fiers, M.; Schat, H.; et al. Arabidopsis thaliana transcription factors bZIP19 and bZIP23 regulate the adaptation to zinc deficiency. Proc. Natl. Acad. Sci. USA 2010, 107, 10296-10301. [CrossRef]

58. Nishida, S.; Mizuno, T.; Obata, H. Involvement of histidine-rich domain of ZIP family transporter TjZNT1 in metal ion specificity. Plant Physiol. Biochem. 2008, 46, 601-606. [CrossRef]

59. Gustin, J.L.; Loureiro, M.E.; Kim, D.; Na, G.; Tikhonova, M.; Salt, D.E. MTP1-dependent Zn sequestration into shoot vacuoles suggests dual roles in $\mathrm{Zn}$ tolerance and accumulation in Zn-hyperaccumulating plants. Plant J. Cell Mol. Biol. 2009, 57, 1116-1127. [CrossRef] [PubMed]

60. Kobae, Y.; Sekino, T.; Yoshioka, H.; Nakagawa, T.; Martinoia, E.; Maeshima, M. Loss of AtPDR8, a plasma membrane $\mathrm{ABC}$ transporter of Arabidopsis thaliana, causes hypersensitive cell death upon pathogen infection. Plant Cell Physiol. 2006, 47, 309-318. [CrossRef] [PubMed]

61. Kim, D.Y.; Bovet, L.; Maeshima, M.; Martinoia, E.; Lee, Y. The ABC transporter AtPDR8 is a cadmium extrusion pump conferring heavy metal resistance. Plant J. Cell Mol. Biol. 2007, 50, 207-218. [CrossRef]

62. Zayed, A.; Lytle, C.M.; Qian, J.-H.; Terry, N. Chromium accumulation, translocation and chemical speciation in vegetable crops. Planta 1998, 206, 293-299. [CrossRef]

63. Cary, E.E.; Allaway, W.H.; Olson, O.E. Control of chromium concentrations in food plants. 1. Absorption and translocation of chromium by plants. J. Agric. Food Chem. 1977, 25, 300-304. [CrossRef] [PubMed]

64. Mallick, S.; Sinam, G.; Kumar Mishra, R.; Sinha, S. Interactive effects of Cr and Fe treatments on plants growth, nutrition and oxidative status in Zea mays L. Ecotoxicol. Environ. Saf. 2010, 73, 987-995. [CrossRef] [PubMed]

65. Chigonum, W.J.; Ikenna, O.C.; John, C.U. Dynamic Impact of Chromium on Nutrient Uptake from Soil by Fluted Pumpkin (Telfairia occidentalis). Am. J. Biosci. Bioeng. 2019, 7, 1-9.

66. Osu Charles, I.; Onyema, M.O. Vanadium inhibition capacity on nutrients and heavy metal uptake by Cucumis Sativus. J. Am. Sci. 2016, 12. [CrossRef]

67. Dube, B.; Tewari, K.; Chatterjee, J.; Chatterjee, C. Excess chromium alters uptake and translocation of certain nutrients in citrullus. Chemosphere 2003, 53, 1147-1153. [CrossRef]

68. Turner, M.; Rust, R. Effects of Chromium on Growth and Mineral Nutrition of Soybeans 1. Soil Sci. Soc. Am. J. 1971, 35, 755-758. [CrossRef]

69. Sundaramoorthy, P.; Chidambaram, A.; Ganesh, K.S.; Unnikannan, P.; Baskaran, L. Chromium stress in paddy: (i) nutrient status of paddy under chromium stress; (ii) phytoremediation of chromium by aquatic and terrestrial weeds. C. R. Biol. 2010, 333, 597-607. [CrossRef] [PubMed]

70. Shahzad, B.; Tanveer, M.; Rehman, A.; Cheema, S.A.; Fahad, S.; Rehman, S.; Sharma, A. Nickel; whether toxic or essential for plants and environment-A review. Plant Physiol. Biochem. 2018, 132, 641-651. [CrossRef] [PubMed]

71. Mengel, K.; Kirkby, E. Principles of Plant Nutrition; International Potash Institute: Worblaufen, Switzerland, 1987; pp. 687-695. 
72. Rai, V.; Tandon, P.K.; Khatoon, S. Effect of chromium on antioxidant potential of Catharanthus roseus varieties and production of their anticancer alkaloids: Vincristine and vinblastine. BioMed Res. Int. 2014, 2014, 1-10. [CrossRef] [PubMed]

73. Lushchak, V.I. Adaptive response to oxidative stress: Bacteria, fungi, plants and animals. Comp. Biochem. Physiol. Part C Toxicol. Pharmacol. 2011, 153, 175-190. [CrossRef]

74. Sharma, A.; Kumar, V.; Shahzad, B.; Ramakrishnan, M.; Sidhu, G.P.S.; Bali, A.S.; Handa, N.; Kapoor, D.; Yadav, P.; Khanna, K. Photosynthetic Response of Plants Under Different Abiotic Stresses: A Review. J. Plant Growth Regul. 2019, 38, 1-23. [CrossRef]

75. Valko, M.; Rhodes, C.; Moncol, J.; Izakovic, M.; Mazur, M. Free radicals, metals and antioxidants in oxidative stress-induced cancer. Chem.-Biol. Interact. 2006, 160, 1-40. [CrossRef]

76. Chandra, P.; Kulshreshtha, K. Chromium accumulation and toxicity in aquatic vascular plants. Bot. Rev. 2004, 70, 313-327. [CrossRef]

77. Hayat, S.; Khalique, G.; Irfan, M.; Wani, A.S.; Tripathi, B.N.; Ahmad, A. Physiological changes induced by chromium stress in plants: An overview. Protoplasma 2012, 249, 599-611. [CrossRef]

78. Rajendran, M.; An, W.-H.; Li, W.-C.; Perumal, V.; Wu, C.; Sahi, S.V.; Sarkar, S.K. Chromium detoxification mechanism induced growth and antioxidant responses in vetiver (Chrysopogon zizanioides (L.) Roberty). J. Cent. South Univ. 2019, 26, 489-500. [CrossRef]

79. Sinha, S.; Saxena, R.; Singh, S. Chromium induced lipid peroxidation in the plants of Pistia stratiotes L.: Role of antioxidants and antioxidant enzymes. Chemosphere 2005, 58, 595-604. [CrossRef]

80. Balal, R.M.; Shahid, M.A.; Vincent, C.; Zotarelli, L.; Liu, G.; Mattson, N.S.; Rathinasabapathi, B.; Martínez-Nicolas, J.J.; Garcia-Sanchez, F. Kinnow mandarin plants grafted on tetraploid rootstocks are more tolerant to Cr-toxicity than those grafted on its diploids one. Environ. Exp. Bot. 2017, 140, 8-18. [CrossRef]

81. Islam, F.; Yasmeen, T.; Arif, M.S.; Riaz, M.; Shahzad, S.M.; Imran, Q.; Ali, I. Combined ability of chromium (Cr) tolerant plant growth promoting bacteria (PGPB) and salicylic acid (SA) in attenuation of chromium stress in maize plants. Plant Physiol. Biochem. 2016, 108, 456-467. [CrossRef] [PubMed]

82. Zou, J.; Yu, K.; Zhang, Z.; Jiang, W.; Liu, D. Antioxidant response system and chlorophyll fluorescence in chromium (VI)-treated Zea mays L. seedlings. Acta Biol. Crac. Ser. Bot. 2009, 51, 23-33.

83. Amin, H.; Arain, B.A.; Amin, F.; Surhio, M.A. Phytotoxicity of chromium on germination, growth and biochemical attributes of Hibiscus esculentus L. Am. J. Plant Sci. 2013, 4, 720-726. [CrossRef]

84. Tang, J.; Xu, J.; Wu, Y.; Li, Y.; Tang, Q. Effects of high concentration of chromium stress on physiological and biochemical characters and accumulation of chromium in tea plant (Camellia sinensis. L.). Afr. J. Biotechnol. 2012, 11, 2248-2255.

85. Amin, H.; Arain, B.A.; Amin, F.; Surhio, M.A. Analysis of growth response and tolerance index of Glycine max (L.) Merr. under hexavalent chromium stress. Adv. Life Sci. 2014, 1, 231-241.

86. Muslu, A.; Ergün, N. Effects of copper and chromium and high temperature on growth, proline and protein content in wheat seedlings. Bangladesh J. Bot. 2013, 42, 105-112. [CrossRef]

87. Van Assche, F.; Clijsters, H. Effects of metals on enzyme activity in plants. Plant Cell Environ. 1990, 13, 195-206. [CrossRef]

88. Vajpayee, P.; Rai, U.; Ali, M.; Tripathi, R.; Yadav, V.; Sinha, S.; Singh, S. Chromium-induced physiologic changes in Vallisneria spiralis L. and its role in phytoremediation of tannery effluent. Bull. Environ. Contam. Toxicol. 2001, 67, 246-256. [CrossRef]

89. Zlobin, I.; Kholodova, V.; Rakhmankulova, Z.; Kuznetsov, V.V. Brassica napus responses to short-term excessive copper treatment with decrease of photosynthetic pigments, differential expression of heavy metal homeostasis genes including activation of gene NRAMP4 involved in photosystem II stabilization. Photosynth. Res. 2015, 125, 141-150. [CrossRef]

90. Vernay, P.; Gauthier-Moussard, C.; Hitmi, A. Interaction of bioaccumulation of heavy metal chromium with water relation, mineral nutrition and photosynthesis in developed leaves of Lolium perenne L. Chemosphere 2007, 68, 1563-1575. [CrossRef] [PubMed]

91. Khan, I.; Iqbal, M.; Ashraf, M.Y.; Ashraf, M.A.; Ali, S. Organic chelants-mediated enhanced lead (Pb) uptake and accumulation is associated with higher activity of enzymatic antioxidants in spinach (Spinacea oleracea L.). J. Hazard. Mater. 2016, 317, 352-361. [CrossRef] [PubMed]

92. Sharma, S.S.; Dietz, K.-J. The significance of amino acids and amino acid-derived molecules in plant responses and adaptation to heavy metal stress. J. Exp. Bot. 2006, 57, 711-726. [CrossRef] [PubMed] 
93. Sharma, D.; Sharma, C. Chromium uptake and toxicity effects on growth and metabolic activities in wheat, Triticum aestivum L. cv. UP 2003. Indian J. Exp. Biol. 1996, 34, 689-691. [PubMed]

94. Sharma, A.; Shahzad, B.; Rehman, A.; Bhardwaj, R.; Landi, M.; Zheng, B. Response of phenylpropanoid pathway and the role of polyphenols in plants under abiotic stress. Molecules 2019, 24, 2452. [CrossRef]

95. Shakoor, M.B.; Ali, S.; Hameed, A.; Farid, M.; Hussain, S.; Yasmeen, T.; Najeeb, U.; Bharwana, S.A.; Abbasi, G.H. Citric acid improves lead $(\mathrm{Pb})$ phytoextraction in Brassica napus L. by mitigating Pb-induced morphological and biochemical damages. Ecotoxicol. Environ. Saf. 2014, 109, 38-47. [CrossRef]

96. Davies, F., Jr.; Puryear, J.; Newton, R.; Egilla, J.; Saraiva Grossi, J. Mycorrhizal fungi increase chromium uptake by sunflower plants: Influence on tissue mineral concentration, growth, and gas exchange. J. Plant Nutr. 2002, 25, 2389-2407. [CrossRef]

97. Handa, N.; Kohli, S.K.; Sharma, A.; Thukral, A.K.; Bhardwaj, R.; Abd_Allah, E.F.; Alqarawi, A.A.; Ahmad, P. Selenium modulates dynamics of antioxidative defence expression, photosynthetic attributes and secondary metabolites to mitigate chromium toxicity in Brassica juncea L. plants. Environ. Exp. Bot. 2019, 161, 180-192. [CrossRef]

98. Radi, R. Oxygen radicals, nitric oxide, and peroxynitrite: Redox pathways in molecular medicine. Proc. Natl. Acad. Sci. USA 2018, 115, 5839-5848. [CrossRef]

99. Pisoschi, A.M.; Pop, A. The role of antioxidants in the chemistry of oxidative stress: A review. Eur. J. Med. Chem. 2015, 97, 55-74. [CrossRef]

100. Turkan, I.; Uzilday, B.; Dietz, K.J.; Brautigam, A.; Ozgur, R. Reactive oxygen species and redox regulation in mesophyll and bundle sheath cells of C4 plants. J. Exp. Bot. 2018, 69, 3321-3331. [CrossRef] [PubMed]

101. Valko, M.; Leibfritz, D.; Moncol, J.; Cronin, M.T.; Mazur, M.; Telser, J. Free radicals and antioxidants in normal physiological functions and human disease. Int. J. Biochem. Cell Biol. 2007, 39, 44-84. [CrossRef] [PubMed]

102. Shahzad, B.; Tanveer, M.; Che, Z.; Rehman, A.; Cheema, S.A.; Sharma, A.; Song, H.; Ur Rehman, S.; Zhaorong, D. Role of 24-epibrassinolide (EBL) in mediating heavy metal and pesticide induced oxidative stress in plants: A review. Ecotoxicol. Environ. Saf. 2018, 147, 935-944. [CrossRef] [PubMed]

103. Anjum, S.A.; Tanveer, M.; Hussain, S.; Ullah, E.; Wang, L.; Khan, I.; Samad, R.A.; Tung, S.A.; Anam, M.; Shahzad, B. Morpho-physiological growth and yield responses of two contrasting maize cultivars to cadmium exposure. Clean-Soil Air Water 2016, 44, 29-36. [CrossRef]

104. Anjum, S.A.; Tanveer, M.; Hussain, S.; Bao, M.; Wang, L.; Khan, I.; Ullah, E.; Tung, S.A.; Samad, R.A.; Shahzad, B. Cadmium toxicity in Maize (Zea mays L.): Consequences on antioxidative systems, reactive oxygen species and cadmium accumulation. Environ. Sci. Pollut. Res. 2015, 22, 17022-17030. [CrossRef]

105. Grover, P.; Rekhadevi, P.; Danadevi, K.; Vuyyuri, S.; Mahboob, M.; Rahman, M. Genotoxicity evaluation in workers occupationally exposed to lead. Int. J. Hyg. Environ. Health 2010, 213, 99-106. [CrossRef]

106. Opdenakker, K.; Remans, T.; Keunen, E.; Vangronsveld, J.; Cuypers, A. Exposure of Arabidopsis thaliana to $\mathrm{Cd}$ or $\mathrm{Cu}$ excess leads to oxidative stress mediated alterations in MAPKinase transcript levels. Environ. Exp. Bot. 2012, 83, 53-61. [CrossRef]

107. Tanveer, M.; Shahzad, B.; Sharma, A.; Khan, E.A. 24-Epibrassinolide application in plants: An implication for improving drought stress tolerance in plants. Plant Physiol. Biochem. 2018, 135, 295-303. [CrossRef]

108. Tanveer, M.; Shahzad, B.; Sharma, A.; Biju, S.; Bhardwaj, R. 24-Epibrassinolide; an active brassinolide and its role in salt stress tolerance in plants: A review. Plant Physiol. Biochem. 2018, 130, 69-79. [CrossRef]

109. Shahzad, B.; Mughal, M.N.; Tanveer, M.; Gupta, D.; Abbas, G. Is lithium biologically an important or toxic element to living organisms? An overview. Environ. Sci. Pollut. Res. 2017, 24, 103-115. [CrossRef]

110. Anjum, S.A.; Tanveer, M.; Hussain, S.; Shahzad, B.; Ashraf, U.; Fahad, S.; Hassan, W.; Jan, S.; Khan, I.; Saleem, M.F. Osmoregulation and antioxidant production in maize under combined cadmium and arsenic stress. Environ. Sci. Pollut. Res. 2016, 23, 11864-11875. [CrossRef] [PubMed]

111. Morina, F.; Jovanovic, L.; Mojovic, M.; Vidovic, M.; Pankovic, D.; Veljovic Jovanovic, S. Zinc-induced oxidative stress in Verbascum thapsus is caused by an accumulation of reactive oxygen species and quinhydrone in the cell wall. Physiol. Plant. 2010, 140, 209-224. [CrossRef] [PubMed]

112. Kováčik, J.; Klejdus, B.; Hedbavny, J.; Bačkor, M. Effect of copper and salicylic acid on phenolic metabolites and free amino acids in Scenedesmus quadricauda (Chlorophyceae). Plant Sci. 2010, 178, 307-311. [CrossRef]

113. Duquesnoy, I.; Champeau, G.M.; Evray, G.; Ledoigt, G.; Piquet-Pissaloux, A. Enzymatic adaptations to arsenic-induced oxidative stress in Zea mays and genotoxic effect of arsenic in root tips of Vicia faba and Zea mays. C. R. Biol. 2010, 333, 814-824. [CrossRef] 
114. Márquez-García, B.; Pérez-López, R.; Ruíz-Chancho, M.J.; López-Sánchez, J.F.; Rubio, R.; Abreu, M.M.; Nieto, J.M.; Córdoba, F. Arsenic speciation in soils and Erica andevalensis Cabezudo \& Rivera and Erica australis L. from São Domingos Mine area, Portugal. J. Geochem. Explor. 2012, 119, 51-59.

115. Körpe, D.A.; Aras, S. Evaluation of copper-induced stress on eggplant (Solanum melongena L.) seedlings at the molecular and population levels by use of various biomarkers. Mutat. Res./Genet. Toxicol. Environ. Mutagenesis 2011, 719, 29-34. [CrossRef]

116. Jozefczak, M.; Remans, T.; Vangronsveld, J.; Cuypers, A. Glutathione is a key player in metal-induced oxidative stress defenses. Int. J. Mol. Sci. 2012, 13, 3145-3175. [CrossRef]

117. Gupta, D.; Nicoloso, F.; Schetinger, M.; Rossato, L.; Pereira, L.; Castro, G.; Srivastava, S.; Tripathi, R. Antioxidant defense mechanism in hydroponically grown Zea mays seedlings under moderate lead stress. J. Hazard. Mater. 2009, 172, 479-484. [CrossRef]

118. Gupta, D.; Huang, H.; Yang, X.; Razafindrabe, B.; Inouhe, M. The detoxification of lead in Sedum alfredii H. is not related to phytochelatins but the glutathione. J. Hazard. Mater. 2010, 177, 437-444. [CrossRef]

119. Shahzad, B.; Tanveer, M.; Hassan, W.; Shah, A.N.; Anjum, S.A.; Cheema, S.A.; Ali, I. Lithium toxicity in plants: Reasons, mechanisms and remediation possibilities-A review. Plant Physiol. Biochem. 2016, 107, 104-115. [CrossRef]

120. Lee, S.; Moon, J.S.; Ko, T.-S.; Petros, D.; Goldsbrough, P.B.; Korban, S.S. Overexpression of Arabidopsis phytochelatin synthase paradoxically leads to hypersensitivity to cadmium stress. Plant Physiol. 2003, 131, 656-663. [CrossRef] [PubMed]

121. Weyemi, U.; Dupuy, C. The emerging role of ROS-generating NADPH oxidase NOX4 in DNA-damage responses. Mutat. Res./Rev. Mutat. Res. 2012, 751,77-81. [CrossRef]

122. Potocký, M.; Pejchar, P.; Gutkowska, M.; Jiménez-Quesada, M.J.; Potocká, A.; de Dios Alché, J.; Kost, B.; Žárský, V. NADPH oxidase activity in pollen tubes is affected by calcium ions, signaling phospholipids and Rac/Rop GTPases. J. Plant Physiol. 2012, 169, 1654-1663. [CrossRef] [PubMed]

123. Pourrut, B.; Shahid, M.; Douay, F.; Dumat, C.; Pinelli, E. Molecular mechanisms involved in lead uptake, toxicity and detoxification in higher plants. In Heavy Metal Stress in Plants; Springer: Berlin/Heidelberg, Germany, 2013; pp. 121-147.

124. Pourrut, B.; Perchet, G.; Silvestre, J.; Cecchi, M.; Guiresse, M.; Pinelli, E. Potential role of NADPH-oxidase in early steps of lead-induced oxidative burst in Vicia faba roots. J. Plant Physiol. 2008, 165, 571-579. [CrossRef] [PubMed]

125. Sagi, M.; Fluhr, R. Production of reactive oxygen species by plant NADPH oxidases. Plant Physiol. 2006, 141, 336-340. [CrossRef]

126. Choudhury, S.; Panda, S.K. Toxic effects, oxidative stress and ultrastructural changes in moss Taxithelium nepalense (Schwaegr.) Broth. under chromium and lead phytotoxicity. Water Air Soil Pollut. 2005, 167, 73-90. [CrossRef]

127. Ullah, A.; Shahzad, B.; Tanveer, M.; Nadeem, F.; Sharma, A.; Lee, D.J.; Rehman, A. Abiotic Stress Tolerance in Plants Through Pre-sowing Seed Treatments with Mineral Elements and Growth Regulators. In Priming and Pretreatment of Seeds and Seedlings: Implication in Plant Stress Tolerance and Enhancing Productivity in Crop Plants; Hasanuzzaman, M., Fotopoulos, V., Eds.; Springer: Singapore, 2019; pp. 427-445. [CrossRef]

128. Fahad, S.; Rehman, A.; Shahzad, B.; Tanveer, M.; Saud, S.; Kamran, M.; Ihtisham, M.; Khan, S.U.; Turan, V.; Ur Rahman, M.H. Chapter 14-Rice Responses and Tolerance to Metal/Metalloid Toxicity. Advances in Rice Research for Abiotic Stress Tolerance 2019, 299-312. [CrossRef]

129. Adrees, M.; Ali, S.; Iqbal, M.; Bharwana, S.A.; Siddiqi, Z.; Farid, M.; Ali, Q.; Saeed, R.; Rizwan, M. Mannitol alleviates chromium toxicity in wheat plants in relation to growth, yield, stimulation of anti-oxidative enzymes, oxidative stress and $\mathrm{Cr}$ uptake in sand and soil media. Ecotoxicol. Environ. Saf. 2015, 122, 1-8. [CrossRef]

130. Gill, S.S.; Tuteja, N. Reactive oxygen species and antioxidant machinery in abiotic stress tolerance in crop plants. Plant Physiol. Biochem. 2010, 48, 909-930. [CrossRef]

131. Bhaduri, A.M.; Fulekar, M. Antioxidant enzyme responses of plants to heavy metal stress. Rev. Environ. Sci. Bio/Technol. 2012, 11, 55-69. [CrossRef]

132. Panda, S.; Choudhury, S. Chromium stress in plants. Braz. J. Plant Physiol. 2005, 17, 95-102. [CrossRef] 
133. Mhamdi, A.; Hager, J.; Chaouch, S.; Queval, G.; Han, Y.; Taconnat, L.; Saindrenan, P.; Gouia, H.; Issakidis-Bourguet, E.; Renou, J.-P. Arabidopsis GLUTATHIONE REDUCTASE1 plays a crucial role in leaf responses to intracellular hydrogen peroxide and in ensuring appropriate gene expression through both salicylic acid and jasmonic acid signaling pathways. Plant Physiol. 2010, 153, 1144-1160. [CrossRef] [PubMed]

134. Wu, H.; Tito, N.; Giraldo, J.P. Anionic Cerium Oxide Nanoparticles Protect Plant Photosynthesis from Abiotic Stress by Scavenging Reactive Oxygen Species. ACS Nano 2017, 11, 11283-11297. [CrossRef] [PubMed]

135. Anjum, S.A.; Ashraf, U.; Tanveer, M.; Khan, I.; Hussain, S.; Shahzad, B.; Zohaib, A.; Abbas, F.; Saleem, M.F.; Ali, I.; et al. Drought Induced Changes in Growth, Osmolyte Accumulation and Antioxidant Metabolism of Three Maize Hybrids. Front. Plant Sci. 2017, 8, 69. [CrossRef]

136. Sharma, D.; Sharma, C.; Tripathi, R. Phytotoxic lesions of chromium in maize. Chemosphere 2003, 51, $63-68$. [CrossRef]

137. Ali, S.; Chaudhary, A.; Rizwan, M.; Anwar, H.T.; Adrees, M.; Farid, M.; Irshad, M.K.; Hayat, T.; Anjum, S.A. Alleviation of chromium toxicity by glycinebetaine is related to elevated antioxidant enzymes and suppressed chromium uptake and oxidative stress in wheat (Triticum aestivum L.). Environ. Sci. Pollut. Res. 2015, 22, 10669-10678. [CrossRef]

138. Alscher, R.G.; Donahue, J.L.; Cramer, C.L. Reactive oxygen species and antioxidants: Relationships in green cells. Physiol. Plant. 1997, 100, 224-233. [CrossRef]

139. Blokhina, O.; Virolainen, E.; Fagerstedt, K.V. Antioxidants, oxidative damage and oxygen deprivation stress: A review. Ann. Bot. 2003, 91, 179-194. [CrossRef]

140. Kasote, D.M.; Katyare, S.S.; Hegde, M.V.; Bae, H. Significance of antioxidant potential of plants and its relevance to therapeutic applications. Int. J. Biol. Sci. 2015, 11, 982-991. [CrossRef]

141. Meyer, A.J.; Hell, R. Glutathione homeostasis and redox-regulation by sulfhydryl groups. Photosynth. Res. 2005, 86, 435-457. [CrossRef] [PubMed]

142. Noctor, G.; Mhamdi, A.; Chaouch, S.; Han, Y.; Neukermans, J.; Marquez-Garcia, B.; Queval, G.; Foyer, C.H. Glutathione in plants: An integrated overview. Plant Cell Environ. 2012, 35, 454-484. [CrossRef] [PubMed]

143. Galant, A.; Preuss, M.L.; Cameron, J.C.; Jez, J.M. Plant glutathione biosynthesis: Diversity in biochemical regulation and reaction products. Front. Plant Sci. 2011, 2, 45. [CrossRef] [PubMed]

144. Noctor, G.; Foyer, C.H. Simultaneous measurement of foliar glutathione, $\gamma$-glutamylcysteine, and amino acids by high-performance liquid chromatography: Comparison with two other assay methods for glutathione. Anal. Biochem. 1998, 264, 98-110. [CrossRef] [PubMed]

145. Di Toppi, L.S.; Fossati, F.; Musetti, R.; Mikerezi, I.; Favali, M.A. Effects of Hexavalent Chromium on Maize, Tomato, and Cauliflower Plants. J. Plant Nutr. 2002, 25, 701-717. [CrossRef]

146. Shanker, A.K.; Pathmanabhan, G. Speciation dependant antioxidative response in roots and leaves of sorghum (Sorghum bicolor (L.) Moench cv CO 27) under Cr (III) and Cr (VI) stress. Plant Soil 2004, 265, 141-151. [CrossRef]

147. McAuley, A.; Olatunji, M.A. Metal-ion oxidations in solution. Part XIX. Redox pathways in the oxidation of penicillamine and glutathione by chromium (VI). Can. J. Chem. 1977, 55, 3335-3340. [CrossRef]

148. Marwa, E.M.; Meharg, A.A.; Rice, C.M. Risk assessment of potentially toxic elements in agricultural soils and maize tissues from selected districts in Tanzania. Sci. Total. Environ. 2012, 416, 180-186. [CrossRef]

149. Kumar, V.; Yadav, S.K. Proline and betaine provide protection to antioxidant and methylglyoxal detoxification systems during cold stress in Camellia sinensis (L.) O. Kuntze. Acta Physiol. Plant. 2009, 31, 261-269. [CrossRef]

150. Ganesh, K.S.; Baskaran, L.; Chidambaram, A.; Sundaramoorthy, P. Influence of chromium stress on proline accumulation in soybean (Glycine max L. Merr.) genotypes. Glob. J. Environ. Res. 2009, 3, 106-108.

151. Bitrián, M.; Zarza, X.; Altabella, T.; Tiburcio, A.F.; Alcázar, R. Polyamines under abiotic stress: Metabolic crossroads and hormonal crosstalks in plants. Metabolites 2012, 2, 516-528. [CrossRef]

152. Hussain, M.I.; González, L.; Souto, C.; Reigosa, M. Ecophysiological responses of three native herbs to phytotoxic potential of invasive Acacia melanoxylon R. Br. Agrofor. Syst. 2011, 83, 149-166. [CrossRef]

153. Davies, P.J. Plant Hormones: Biosynthesis, Signal Transduction, Action; Springer: Berlin/Heidelberg, Germany, 2004.

154. Skirycz, A.; Inzé, D. More from less: Plant growth under limited water. Curr. Opin. Biotechnol. 2010, 21, 197-203. [CrossRef] [PubMed] 
155. O’Brien, J.A.; Benková, E. Cytokinin cross-talking during biotic and abiotic stress responses. Front. Plant Sci. 2013, 4, 451. [CrossRef] [PubMed]

156. Huang, T.L.; Nguyen, Q.T.; Fu, S.F.; Lin, C.Y.; Chen, Y.C.; Huang, H.J. Transcriptomic changes and signalling pathways induced by arsenic stress in rice roots. Plant Mol. Biol. 2012, 80, 587-608. [CrossRef]

157. Rivas-San Vicente, M.; Plasencia, J. Salicylic acid beyond defence: Its role in plant growth and development. J. Exp. Bot. 2011, 62, 3321-3338. [CrossRef]

158. Miura, K.; Tada, Y. Regulation of water, salinity, and cold stress responses by salicylic acid. Front. Plant Sci. 2014, 5, 4. [CrossRef]

159. Jia, C.; Zhang, L.; Liu, L.; Wang, J.; Li, C.; Wang, Q. Multiple phytohormone signalling pathways modulate susceptibility of tomato plants to Alternaria alternata f. sp. lycopersici. J. Exp. Bot. 2013, 64, 637-650. [CrossRef]

160. Khanna, P.; Kaur, K.; Gupta, A.K. Salicylic acid induces differential antioxidant response in spring maize under high temperature stress. Indian J. Exp. Biol. 2016, 54, 386-393.

161. Matilla-Vazquez, M.; Matilla, A. Ethylene: Role in plants under environmental stress. In Physiological Mechanisms and Adaptation Strategies in Plants under Changing Environment; Springer: Berlin/Heidelberg, Germany, 2014; pp. 189-222.

162. Kazan, K. Auxin and the integration of environmental signals into plant root development. Ann. Bot. 2013, 112, 1655-1665. [CrossRef]

163. Agami, R.A.; Mohamed, G.F. Exogenous treatment with indole-3-acetic acid and salicylic acid alleviates cadmium toxicity in wheat seedlings. Ecotoxicol. Environ. Saf. 2013, 94, 164-171. [CrossRef]

164. Fahad, S.; Hussain, S.; Bano, A.; Saud, S.; Hassan, S.; Shan, D.; Khan, F.A.; Khan, F.; Chen, Y.; Wu, C. Potential role of phytohormones and plant growth-promoting rhizobacteria in abiotic stresses: Consequences for changing environment. Environ. Sci. Pollut. Res. 2015, 22, 4907-4921. [CrossRef] [PubMed]

165. Sponsel, V.; Hedden, P. Gibberellin biosynthesis and inactivation. In Plant Hormones; Davis, P.J., Ed.; Springer: Dordrecht, The Netherlands, 2010; pp. 63-94. [CrossRef]

166. Atici, Ö.; Ağar, G.; Battal, P. Changes in phytohormone contents in chickpea seeds germinating under lead or zinc stress. Biol. Plant. 2005, 49, 215-222. [CrossRef]

167. Ha, S.; Vankova, R.; Yamaguchi-Shinozaki, K.; Shinozaki, K.; Tran, L.-S.P. Cytokinins: Metabolism and function in plant adaptation to environmental stresses. Trends Plant Sci. 2012, 17, 172-179. [CrossRef] [PubMed]

(C) 2020 by the authors. Licensee MDPI, Basel, Switzerland. This article is an open access article distributed under the terms and conditions of the Creative Commons Attribution (CC BY) license (http://creativecommons.org/licenses/by/4.0/). 